\title{
Coexistence of the lingual involvement of glycogen storage disease type III with lichenoid infiltration
}

\section{Glikojen depo hastalığı Tip 3'ün dil tutulumu ile likenoid infiltrasyon birlikteliği}

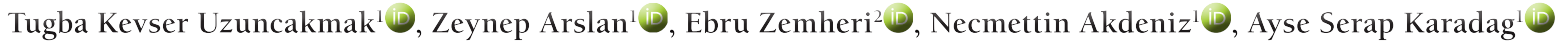 \\ ${ }^{1}$ Dept. of Dermatology, Istanbul Medeniyet University, Goztepe Training and Research Hospital, Istanbul, Turkey, ${ }^{2}$ Dept. of Pathology, Umraniye \\ Training and Research Hospital, Istanbul, Turkey
}

\begin{abstract}
Glycogen storage disease (GSD) type III is an autosomal recessive metabolic disorder and inborn error of metabolism characterized by a deficiency of glycogen debranching enzymes which is affecting 1/100000 every live birth. Clinical presentation is classified into four groups according to the muscular and liver involvement. GSD IIIa, the most common form of GSD III, primarily affects the liver, cardiac muscle, and skeletal muscle. Treatment mainly involves a high-protein diet, to facilitate gluconeogenesis. A 28-year-old male presented to our outpatient clinic with a 2-month history of white asymptomatic lesions on his tongue. He was diagnosed with GSD type 3 when he was six months old, and he has no other systemic disease, drug use or smoking history. A punch biopsy was performed, in superficial dermis band type lymphohistiocytic lichenoid infiltration was detected, also vacuolization of muscle cells and positive PAS staining were seen histologically. Topical high potent corticosteroids and dietary recommendations were offered to him. We want to present this case because of the rarity of lingual muscle involvement in glycogen storage disorders.
\end{abstract}

Key words: lichenoid inflammation, glycogen storage disease, Cori-Forbes disease

O̊zet

Glikojen depo hastalığı (GDH) Tip 3, yaklaşık her 100000 canlı doğumda 1 sıklıkta görülen, glikojenin yıkımını sağlayan enzimlerde defektle karakterize otozomal resesif kalıtılan bir metabolizma hastalığıdır. Klinik bulgularına göre dört ayrı gruba ayrılan bu hastalıkta kas ve karaciğer tutulumu izlenebilmektedir. GDH tip 3a bu grupta en sık görülen alt tiptir ve öncelikle karaciğer, kalp kası ve iskelet kasını etkilemektedir. Tedavide proteinden zengin diyet ile glukoneogenez baskılanması amaçlanmaktadır. Yirmi sekiz yaşında erkek hasta kliniğimize dil üzerinde 2 aydır var olan, herhangi bir yakınmaya neden olmayan beyaz lekeler şikayetiyle başvurdu. Özgeçmi-

Corresponding author: Tugba Kevser Uzuncakmak, Dept. of Dermatology, Istanbul Medeniyet University, Goztepe Training and Research Hospital, Istanbul, Turkey. Phone: +90 530 6640226, E-mail: drtugbakevser@gmail.com

Received: 12 June 2020 Accepted: 26 September 2020

Conflicts of Interest: None

Funding: None

How to cite this article: Uzuncakmak TK, Arslan Z, Zemheri E, Akdeniz N, Karadag AS. Coexistence of the lingual involvement of glycogen storage disease type III with lichenoid infiltration. Mucosa 2020;3:75-79

(c) (i) (-) This work is licensed under a Creative Commons Attribution-NonCommercial 4.0 International License. 
şinde 6 aylıkken glikojen depo hastalığı tanısı aldığı ve diyetle takipte olduğu, ek hastalığının, ilaç kullanımının veya sigara kullanımının olmadığı öğrenildi. Dil üzerinden alınan biyopsinin histopatolojik incelemesinde yüzeyel dermiste bant tarzı lenfositik infiltrasyon, kaslarda vaküolizasyon ve PAS boya ile pozitiflik izlendi. Likenoid infiltrasyona yönelik yüksek güçte yerel kortikosteroid krem ve diyet önerildi. Bu olguyu glikojen depo hastalarında dil kası tutulumunun nadir olması ve karbonhidrat metabolizmasındaki değişikliklerin likenoid reaksiyonlar üzerine olası tetikleyici rolünü vurgulamak amaciyla sunmak istiyoruz.

Anahtar kelimeler: Likenoid inflamasyon, glikojen depo hastalı̆̆, Cori-Forbes hastalı̆̆

\section{Introduction}

Glycogen storage diseases (GSDs) are defined as inherited inborn errors of metabolism (IEM) involving carbohydrate metabolism that is caused by the deficiency of an enzyme involved in either the degradation or synthesis of glycogen and more than 10 subtypes has been identified in the literature. ${ }^{1,2}$ GSDs, depending on the specific type, can present as a failure of converting glycogen into energy and/or a toxic glycogen accumulation that typically affects the liver, striated muscle, or both tissues. ${ }^{2}$ Liver involvement usually causes hepatomegaly and hypoglycemia during fasting, while skeletal muscle involvement causes exercise intolerance, cramping, progressive weakness with variable heart involvement in the form of cardiomyopathy in general practice. The lingual skeletal muscle involvement is very rare in this clinical spectrum.

Oral lichen planus is a chronic condition which is usually affecting the middle-aged or older people, commonly seen in women. ${ }^{3}$ Its etiopathogenesis is unclear but is thought to be associated with cell-mediated immune dysregulation. Within the oral mucosa, buccal mucosa, the tongue, and gingiva are mainly affected. Clinically, the lesions are usually bilateral and may present in multiple forms, such as reticular, plaque-like, erosive, atrophic, and bullous pattern. Oral lichenoid lesions were reported to associated with carbohydrate metabolism disorders. Herein we want to present a young male patient who presented with lichenoid lesions on dorsal aspect of tongue, with a history of glycogen storage disorder. We want to emphasize the possible effect of the proinflammatory role of glycogen deposition on lichenoid inflammation.

\section{Case report}

A 28-year-old male presented with a 2-month history of white asymptomatic patches on the tongue (Fig. 1). He was diagnosed with glycogen storage disease type 3 when he was six months old, and he has no other dermatological or systemic disease including lichen planus, HCV positivity, graft versus host diseases, diabetes, no dental amalgam, no drug use, or smoking history. His laboratory tests were negative for HIV infection and syphilis.

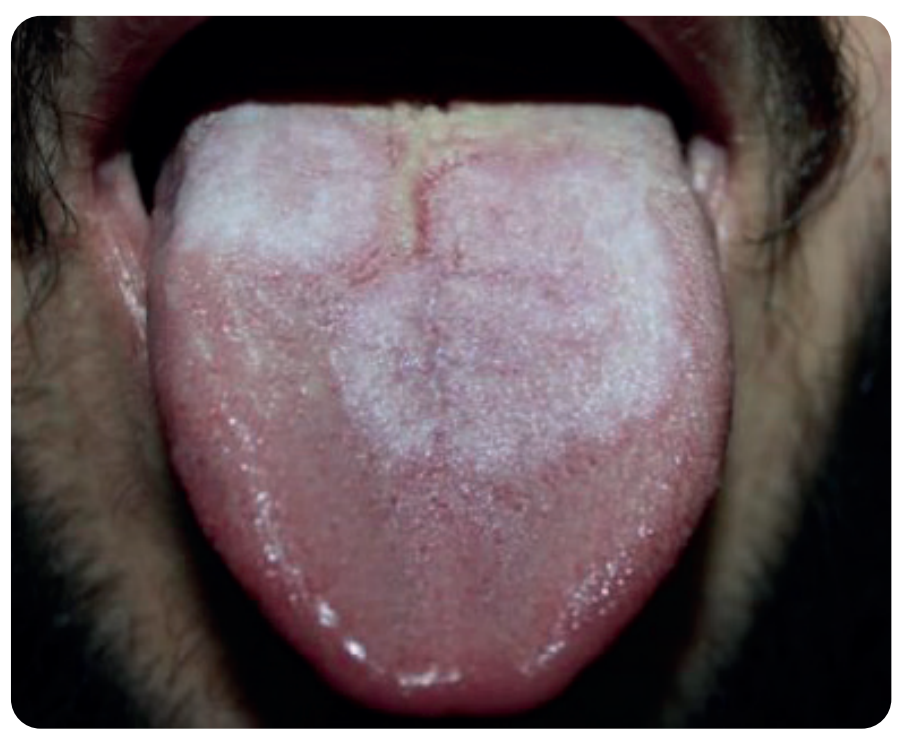

Fig. 1. Extensive homogenous lichenoid keratoses on the mid- and posterior dorsum of the tongue with no erythema, ulceration or speckling

He was under routine follow-ups in internal medicine and neurology departments, there was no history dysarthria, but he had mild myopathy and hepatosplenomegaly on recent magnetic resonance imagination (liver long axis: $180 \mathrm{~mm}$, spleen length: $145 \mathrm{~mm}$ ). In his laboratory tests the liver function tests, creatine kinase and homocysteine levels were higher than nor- 
mal levels (AST: 106 IU/L (<37), ALT: 52 IU/L (<42), CK:3983 IU/L (30-200), Homosistein:34.94 umol/L (516)). No weakness on the tongue or macroglossia was detected in the neurological exam which was performed in the department of neurology. On oral examination, extensive homogenous lichenoid keratoses were present on the mid- and posterior dorsum of the tongue with no erythema, ulceration, or speckling. There were no similar or ulcerated lesions on buccal mucosa and papillae structures all over the tongue. A $4 \mathrm{~mm}$ punch biopsy was performed from the white patch on the dorsum of the tongue for histological evaluation. Histologically, parakeratosis, irregular acanthosis and colloid bodies on the epithelium, and lichenoid lymphocytic infiltration under the epithelia were seen (Fig. 2). In the muscular layer, cytoplasmic vacuolation and accumulation of glycogen with PAS-positivitiy in the cytoplasm of muscle cells were seen. No cytological dysplasia or atypia were detected histologically (Fig. 3). He was diagnosed as lichenoid inflammation co-existing with glycogen storage disorder and we prescribed topical clobetasol propionate cream after histological verification of lichenoid inflammation without any cytological atypia or dysplasia and achieved an excellent clinical response of $100 \%$ clearance without any recurrence in two months. He is still under follow-up free of recurrence for two years.

\section{Discussion}

Cori-Forbes disease which is also known as Type III glycogen storage disease is a rare autosomal recessive disorder that is caused by a deficiency of glycogen debranching enzyme activity located on chromosome $1 \mathrm{p} 21 .{ }^{2}$ Clinically it is characterized by hepatomegaly, hypoglycemia, hyperlipidemia, and growth retardation. The enzyme defect may affect the liver, heart, and skeletal muscles, and therapy is limited to dietary modification including frequent feeding with carbohydrate-rich meals, continuous enteral feeding, or organ transplantation.

In this subtype of GSD, glycogen deposition can occur in many skeletal muscles including the tongue, diaphragm, and heart and the phrenic and sciatic nerves.

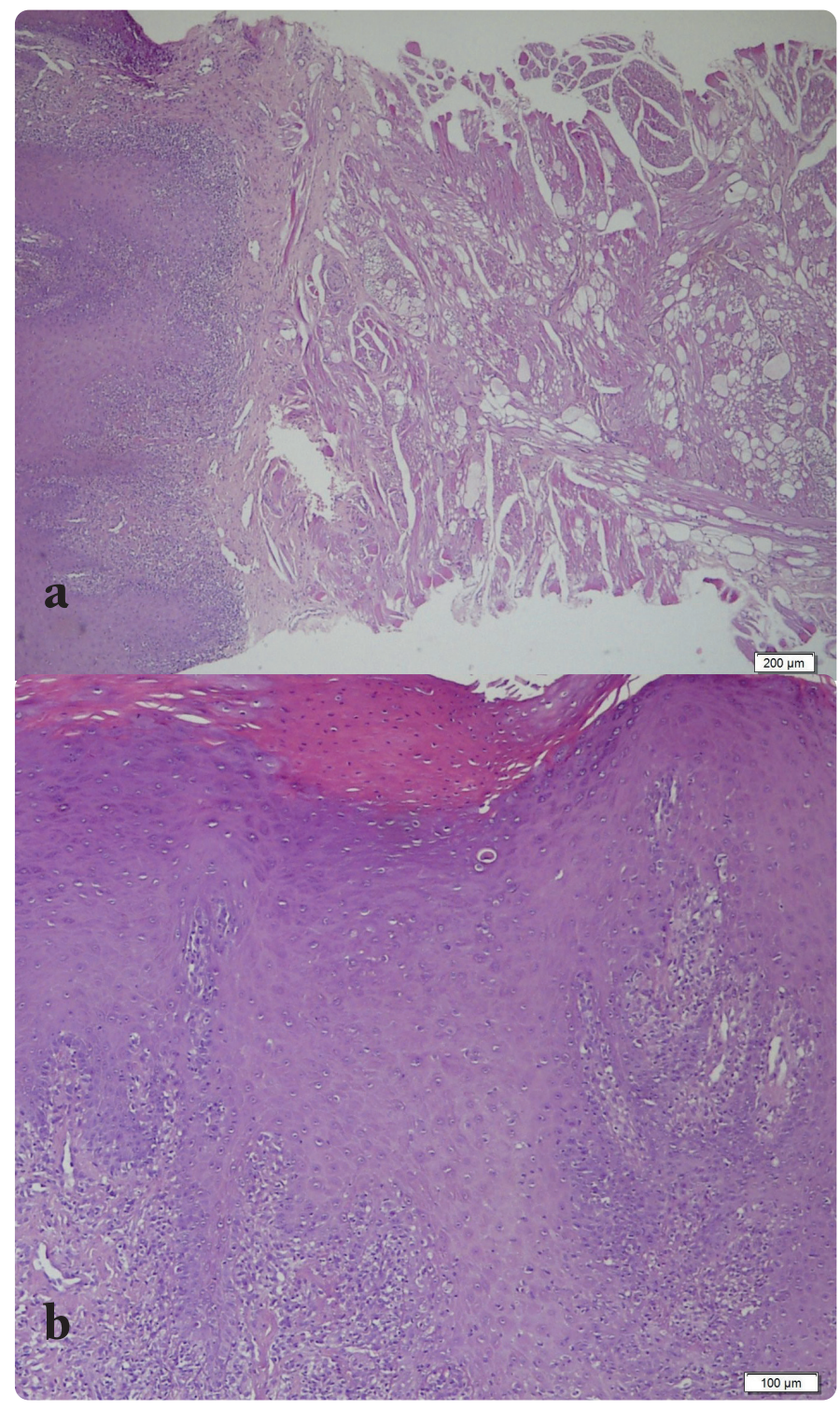

Fig. 2a. Parakeratosis, irregular acanthosis and colloid bodies on the epithelium, and lichenoid lymphocytic infiltration under the epithelia $(H \& E, x 10), 2 b$. Irregular acanthosis and colloid bodies on the epithelium, and lichenoid lymphocytic infiltration under the epithelia (H\&E,x40)

Lingual skeletal muscle involvement is uncommon and reported only in few case series in the literature. ${ }^{4}$ The association of carbohydrate metabolism and lichenoid inflammation is a well-known entity and has been reported to be closely related to carbohydrate intolerance and diabetes mellitus in several observational studies that are characterized by hyperglycemia, not hypoglycemia. ${ }^{5,6}$ The exact role of impaired carbohydrate metabolism is not well understood in the pathoge- 


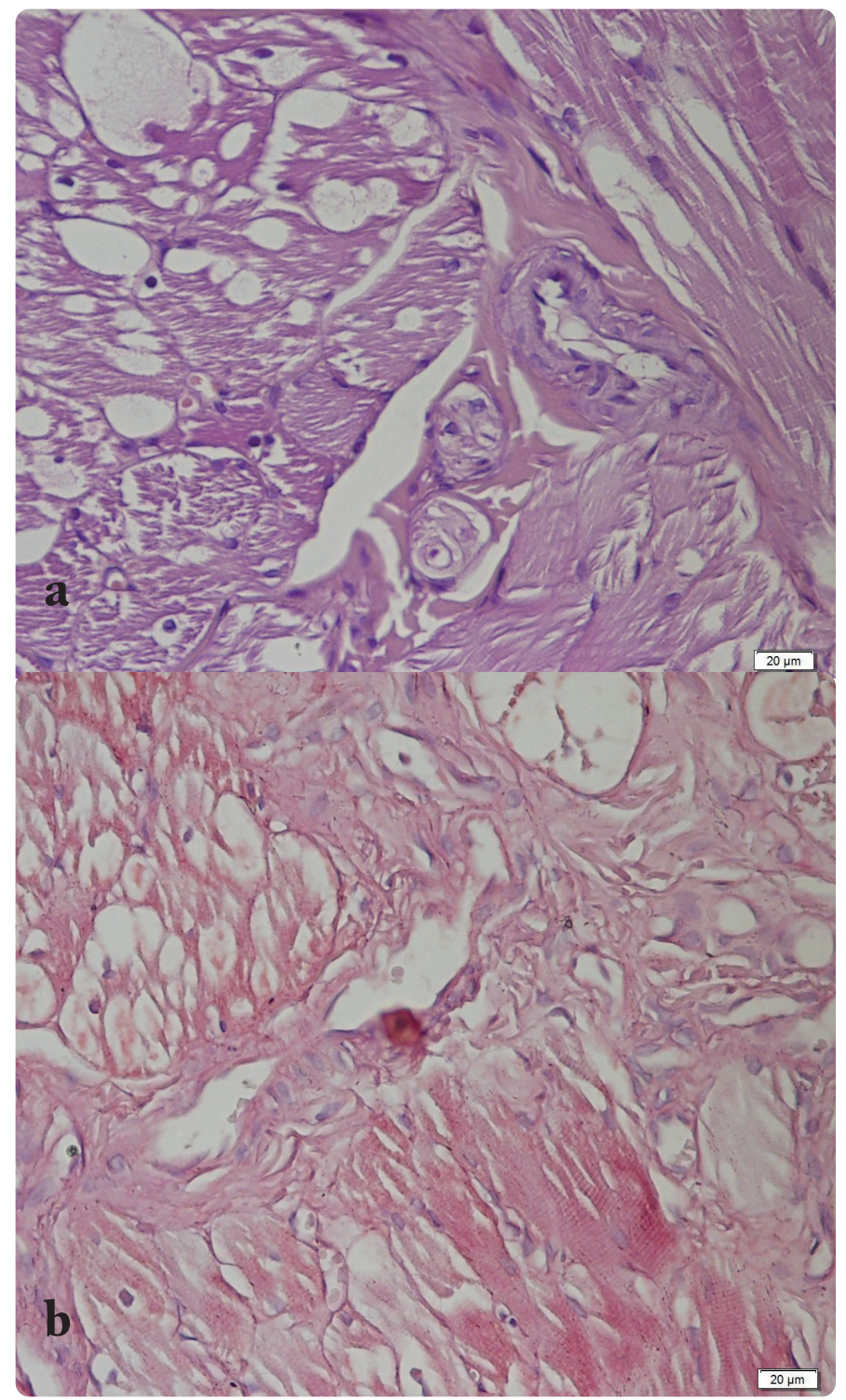

Fig. 3a. Cytoplasmic vacuolation in the cytoplasm of muscle cells (H\&E,x100) b. cytoplasmic vacuolation and accumulation of glycogen with PAS-positivity in cytoplasm of muscle cells (PAS staining, x100)

nesis of lichenoid inflammation. ${ }^{7}$ The proinflammatory role of glycogen accumulation has been shown in adipose tissue by Ceperuelo-Mallafré et al. ${ }^{8}$ before, we think this proinflammatory role of glycogen accumulation may be also related to lichenoid inflammation in our patient. Also, glycogen accumulation was reported to be associated with increased basal Akt/mTOR autophagy flux which has been also shown to be the activated in oral lichenoid lesions which may explain the pathogenesis and tendency of oral lichenoid lesi- ons to possible premalignant transformation. ${ }^{8-10}$ In our patient both clinically and histologically no ulceration was detected. Also, no histological atypia was present in the pathology specimen.

The possible findings of glycogen deposition in the tongue were described by Ding et al. previously in six patients with infantile type glycogen storage disease type II. ${ }^{11}$ They reported varying degrees of generalized muscle weakness, hypotonia in all patients, besides tongue weakness was detected in two of the patients, macroglossia was present in one patient, and hepatomegaly was detected in two patients. Of these findings, only mild hepatomegaly was present in our patient. The subtype of GSD, early treatment, and routine follow-ups may be beneficial in early detection and prevention of the further complications related to glycogen deposition.

Corticosteroids in topical or systemic forms are commonly used agents as first-line therapy in the treatment of oral lichen with variable clinical responses. ${ }^{12}$ We prescribed topical clobetasol propionate cream after histological verification of lichenoid inflammation without any cytological atypia or dysplasia and achieved an excellent clinical response of $100 \%$ clearance without any recurrence in two months. He is still under follow-up free of recurrence for two years. We preferred to prescribe a potent corticosteroid due to more refractory course of oral lichenoid lesions than cutaneous ones.

In conclusion, we present this case because of the rare clinical presentation of lingual muscle involvement of glycogen storage disease, and highlight the possible role of impaired carbohydrate metabolism in lichenoid inflammation.

\section{References}

1. Sun B, Brooks ED, Koeberl DD. Preclinical development of new therapy for glycogen storage diseases. Curr Gene Ther 2015;15:338-47.

2. Kishnani PS, Austin SL, Arn P, et al. Glycogen storage disease type III diagnosis and management guidelines. Genet Med 2010;12:446-63.

3. Thi Do T, Phoomak C, Champattanachai V, Sil- 
sirivanit A, Chaiyarit P. New evidence of connections between increased O-GlcNAcylation and inflammasome in the oral mucosa of patients with oral lichen planus. Clin Exp Immunol 2018;192:129-37.

4. Horvath JJ, Austin SL, Jones HN, et al. Bulbar muscle weakness and fatty lingual infiltration in glycogen storage disorder type IIIa. Mol Genet Metab 2012;107:496-500.

5. Seyhan M, Ozcan H, Sahin I, Bayram N, Karincaoglu Y. High prevalence of glucose metabolism disturbance in patients with lichen planus. Diabetes Res Clin Pract 2007;77:198-202.

6. Romero MA, Seoane J, Varela-Centelles P, Diz-Dios P, Garcia-Pola MJ. Prevalence of diabetes mellitus amongst oral lichen planus patients. Clinical and pathological characteristics. Med Oral 2002;7:121-9.

7. Yamashita T, Ishibashi Y, Nagaoka I, et al. Studies of glycogen induced inflammation of mice. Dynamics of inflammatory responses and influence of antiinflammatory drugs and protease inhibitors. Inflammation 1982;6:87-101.

8. Ceperuelo-Mallafre V, Ejarque M, Serena C, et al. Adipose tissue glycogen accumulation is associated with obesity-linked inflammation in humans. Mol Metab 2015;5:5-18.

9. Zhang N, Zhang J, Tan YQ, et al. Activated Akt/ mTOR-autophagy in local T cells of oral lichen planus. Int Immunopharmacol 2017;48:84-90.

10. van der Meij EH, van der Waal I. Lack of clinicopathologic correlation in the diagnosis of oral lichen planus based on the presently available diagnostic criteria and suggestions for modifications. J Oral Pathol Med 2003;32:507-12.

11. Ding J, Huang Y, Yang H, et al. Analysis of clinical features of 6 patients with infantile type glycogen storage disease type II. Zhonghua Er Ke Za Zhi 2015;53:436-41.

12. Anitua E, Pinas L, Alkhraisat MH. Histopathological features of oral lichen planus and its response to corticosteroid therapy: A retrospective study. Medicine (Baltimore) 2019;98:e18321. 